KALAMATIKA Jurnal Pendidikan Matematika

Volume 2, No. 2, November 2017, hal. 193-206

$\mathbf{K} \backslash \mathbf{L} \wedge \mathbf{M} / \mathbf{T} \mid \mathbf{K} \wedge$

\title{
PROFIL KEMAMPUAN PENALARAN MATEMATIS SISWA DITINJAU DARI GAYA BELAJAR
}

\author{
Muhamad Ridwan \\ Universitas Pendidikan Indonesia \\ muhamad_ridwan@student.upi.edu
}

\begin{abstract}
ABSTRAK
Siswa belajar sesuai dengan gaya belajarnya, dan setiap gaya belajar berpengaruh pada proses penalaran matematis dan hasil belajar. Kombinasi dari bagaimana menyerap, mengatur dan mengolah informasi merupakan definisi dari gaya belajar. Untuk memaksimalkan kemampuan siswa dalam menyerap, mengatur dan mengolah informasi, terlebih dahulu dikenali gaya belajar dari siswa tersebut yaitu visual, auditorial atau kinestetik (V-A-K). Penelitian ini bertujuan untuk mengungkap profil kemampuan penalaran matematis siswa ditinjau dari gaya belajar visual, audio, dan kinestetik pada materi fungsi komposisi dan fungsi invers. Penelitian ini adalah deskriptif kualitatif dengan pendekatan etnographi dan subjek penelitian ini adalah kelas XI SMA. Hasil penelitian profil dari gaya belajar (VA-K) yaitu profil kemampuan penalaran matematis siswa visual memiliki kemampuan memanipulasi, menarik kesimpulan, memberikan alasan atau bukti adalah cukup. Sementara kemampuan memberikan argumennya kurang. Profil kemampuan penalaran matematis siswa auditorial memiliki kemampuan memanipulasi, memberikan alasan atau bukti, dan memberikan argumen atau kesahihan jawaban adalah baik. Sementara menarik kesimpulannya cukup. Profil kemampuan penalaran matematis siswa kinestetik memiliki kemampuan memanipulasi dan memberikan alasan atau bukti adalah cukup. Sedangkan Kemampuan menarik kesimpulannya kurang, serta kemampuan memberikan kesahihan jawaban atau argumen, ia memberikan jawaban dengan unik dan jelas.
\end{abstract}

Kata Kunci : Visual, Auditorial, Kinestetik, Penalaran Matematis.

\begin{abstract}
Students learn according to their learning style, and every learning styles are affecting the process of mathematical reasoning and learning outcomes. The combination of how to absorb, manage and process information is the definition of learning styles. To maximize the students' ability to absorb, manage and process information, first identified learning styles of the students are visual, auditory or kinesthetic (V-A-K). This research aims to reveal the profile of mathematical reasoning abilities of students in terms of learning styles visual, audio and kinesthetic on the material function composition and inverse function. This research is a qualitative descriptive approach ethnography and research subject is grade XI of senior high school. The results of the research of profile learning styles (V-A-K) that profile visual students' mathematical reasoning skill, have the ability to manipulate, draw conclusions, giving reasons or evidence is sufficient. While the ability to deliver his argument lacking. Profile auditory students' mathematical reasoning skills, have the ability to manipulate, giving reason or evidence, and provide argument or the validity of the answer is both. While the ability gets conclusion to enough. Profile kinesthetic students' mathematical reasoning skills have the ability to manipulate and give reasons or evidence is sufficient. The ability to draw conclusions while the less, as
\end{abstract}


well as the ability to provide an answer or the validity of the argument, he answered with a unique and clear.

Keywords: Visual, Auditory, Kinesthetic, Mathematical Reasoning.

Format Sitasi: Ridwan, M. (2017). Profil Kemampuan Penalaran Matematis Siswa di Tinjau dari Gaya Belajar. KALAMATIKA Jurnal Pendidikan Matematika. 2(2), 193-206.

Penyerahan Naskah: 3 Juli 2017 || Revisi: 28 Juli 2017 || Diterima: 1 Agustus 2017

\section{PENDAHULUAN}

Profil adalah suatu gambaran secara garis besar bergantung dari segi mana memandangnya. Jika dipandang dari segi seni, profil dapat diartikan sebagai gambaran atau sketsa tampang atau wajah seseorang yang dilihat dari samping. Dilihat dari segi statistik, profil adalah sekumpulan data yang menjelaskan sesuatu dalam bentuk grafik atau tabel. Sehingga dapat disimpulkan bahwa profil merupakan gambaran secara singkat tentang sesuatu kajian objek tertentu, seperti dalam bentuk grafik, diagram, atau tulisan (Azmi 2013).

Permendiknas Republik Indonesia Nomor 22 Tahun 2006 Tentang Standar Isi menyatakan bahwa salah satu tujuan dari mata pelajaran matematika disekolah yaitu“agar siswa mampu menggunakan penalaran pada pola dan sifat, melakukan manipulasi matematika dalam membuat generalisasi, menyusun bukti, atau menjelaskan gagasan dan pernyataan matematika".Permendikbud Nomor 59 Tahun 2014 Tentang Kurikulum 2013 Sekolah Menengah Atas/Madrasah Aliyah menyatakan bahwa salah satu tujuan diberikannya mata pelajaran matematika yaitu "agar peserta didik mampu mengkomunikasikan gagasan, penalaran serta mampu menyusun bukti matematika dengan menggunakan kalimat lengkap, simbol, tabel, diagram, atau media lain untuk memperjelas keadaan atau masalah".

Kemampuan penalaran merupakan salah satu hal yang harus dimiliki siswa dalam belajar matematika. Selain itu, karena matematika merupakan ilmu yang diperoleh dengan bernalar, tetapi juga karena salah satu tujuan dari pembelajaran matematika adalah agar siswa mampu menggunakan penalaran pada pola dan sifat, melakukan manipulasi matematika dalam membuat generalisasi, menyusun bukti atau menjelaskan gagasan dan pernyataan matematika.

Gaya belajar merupakan sebuah cara pembelajaran unik yang dimiliki setiap individu dalam proses pembelajaran yaitu menyeleksi, menerima, menyerap, menyimpan, mengolah, dan memproses informasi. Dilihat dari profil gaya belajar seseorang, tidak semua orang mempunyai gaya belajar yang sama, sekalipun mereka bersekolah di sekolah sama atau 
bahkan duduk dikelas yang sama. Bahkan kemampuan seseorang untuk memahami dan menyerap pelajaran sudah pasti berbeda tingkatnya, ada yang cepat, sedang dan ada pula yang sangat lambat. Karenanya mereka sering kali menempuh dengan cara yang berbeda untuk bisa memahami sebuah informasi atau pelajaran yang sama. Berkenaan dengan hal tersebut, maka dengan gaya belajar yang berbeda maka kemampuan penalaran matematis pun berbeda pula.

Gaya belajar (Keliat 2016) merupakan salah satu faktor penting yang mampu mempengaruhi prestasi akademik pembelajar, akan tetapi dewasa ini penerapan gaya belajar yang sesuai dengan pembelajar sering terlupakan. DePorter dan Hernacki (2013) mengatakan bahwa kombinasi dari bagaimana menyerap, mengatur dan mengolah informasi merupakan definisi dari gaya belajar. Untuk memaksimalkan kemampuan siswa dalam menyerap, mengatur dan mengolah informasi, terlebih dahulu dikenali gaya belajar dari siswa tersebut yaitu visual, auditorial atau kinestetik (V-A-K). Siswa yang belajar dengan gaya belajar visual cenderung belajar melalui apa yang mereka lihat. Siswa dengan gaya belajar auditorial cenderung belajar melalui apa yang mereka dengar, sedangkan siswa dengan gaya belajar kinestetik cenderung belajar lewat gerakan dan sentuhan. Walaupun masing-masing dari kita belajar menggunakan ketiga modalitas ini pada tahapan tertentu, kebanyakan orang lebih cenderung pada salah satu diantara ketiganya.

Siswa memerlukan kemampuan penalaran matematis baik dalam proses memahami matematika itu sendiri maupun dalam kehidupan sehari-hari. Dalam pembelajaran matematika, kemampuan penalaran berperan baik dalam pemahaman konsep maupun pemecahan masalah (problem solving). Dalam kehidupan sehari-hari, kemampuan bernalar berguna pada saat menyelesaikan permasalahan-permasalahan yang terjadi baik dalam lingkup pribadi, masyarakat dan yang lebih luas lainnya.

Penelitian ini diharapkan mampu mengungkapkan profil kemampuan penalaran matematis seseorang yang ditinjau dari gaya belajar (visual, auditorial, dan kinestetik). Penelitian ini mendeskripsikan secara mendalam profil kemampuan penalaran matematis siswa ditinjau dari gaya belajar pada materi fungsi komposisi dan fungsi invers. Oleh karena itu, penulis tertarik untuk melakukan penelitian dengan judul "Profil Kemampuan Penalaran Matematis Siswa Ditinjau dari Gaya Belajar”. Rumusan masalah dari penelitian ini yaitu: Bagaimana profil kemampuan penalaran matematis siswa ditinjau dari gaya belajar visual, gaya belajar auditorial dan gaya belajar kinestetik dalam menyelesaikan masalah matematika? 
Berdasarkan rumusan masalah di atas, maka tujuan penelitian ini untukmendeskripsikan kemampuan penalaran matematis siswa ditinjau dari gaya belajar visual, gaya belajar auditorial dan gaya belajar kinestetik dalam menyelesaikan masalah matematika.

Penelitian ini diharapkan dapat memberikan manfaat bagi peneliti khususnya dan pihak lain atau pembaca yang sedang dan atauakan mengembangkan penalaran matematis siswa. Secara teoritis dapat memberikan tambahan ilmu mengenai profil kemampuan penalaran matematis siswa yang nantinya dapat diteliti lebih lanjut dengan dengan sudut pandang lain. Secara praktis bermanfaat untuk siswa dan guru, yaitu:

1. Bagi Siswa

Siswa dapat mengetahui gaya belajar apa yang mereka miliki dan bagaimana menyesuaikan dengan kebiasaan yang sering dilakukan siswa dalam keseharian.

2. Bagi Guru

Guru atau pendidik dapat mengetahui gaya belajar dan mengarahkan siswa dan menyesuaikan metode apa yang cocok dengan gaya belajar siswa pada saat-saat proses belajar mengajar.

\section{METODE PENELITIAN}

Penelitian ini adalah penelitian deskriptif kualitatif dengan menggunakan strategi etnografi. Strategi etnografi merupakan salah satu strategi penelitian kualitatif dimana peneliti menyelidiki suatu kelompok yang alamiah dengan mengumpulkan data utama, data observasi, dan data wawancara (Creswell 2013). Melalui penelitian ini, dideskripsikan secara mendalam profil kemampuan penalaran matematis ditinjau dari gaya belajar siswa sesuai dengan faktafakta dokumen terkait dan instrumen pendukung lainnya.

Penelitian ini dilakukan di SMA Negeri 1 Rangkasbitung Kabupaten Lebak. Data penelitian ini, diperoleh dari siswa/siswi SMA Negeri 1 Rangkasbitung. Dengan kata lain, subjek penelitian ini adalah siswa/siswi SMA Negeri 1 Rangkasbitung. Penelitian ini menggunakan teknik purposive sampling untuk menentukan subjek penelitian. Sehingga di dapat subyek penelitiannya adalah siswa/siswi kelas XI IPS SMA Negeri 1 Rangkasbitung.

Penelitian kualitatif instrumen utamanya adalah peneliti itu sendiri, namun selanjutnya setelah fokus penelitian menjadi jelas, maka dikembangkan instrumen penelitian sederhana, yang diharapkan dapat melengkapi dan membandingkan data yang telah ditemukan melalui 
observasi dan wawancara (Sugiyono 2010). Peneliti mengumpulkan data yang dibantu dengan instrumen pendukung yaitu angket penggolongan gaya belajar, tes penalaran matematis dan pedoman wawancara.

Teknik analisis data pada penelitian ini, yaitu sesuai dengan Miles dan Huberman (Sugiyono 2010), mengemukakan aktivitas dalam analisis data, yaitu data reduction, data display, dan verification.

\section{Data Reduction}

Data yang diperoleh dari lapangan jumlahnya cukup banyak, kompleks, dan rumit untuk itu perlu dilakukan analisis data melalui reduksi data. Menurut Sugiyono (2010), mereduksi data berarti merangkum, memilih hal-hal yang pokok, memfokuskan pada hal-hal yang penting, dicari tema dan polanya, dan membuang yang tidak perlu. Data yang telah direduksi, mempermudah peneliti untuk melakukan pengumpulan data selanjutanya karena datanya sudah semakin jelas.

\section{Data Display}

Setelah data direduksi, penyajian data dapat dilakukan dalam bentuk uraian singkat, bagan, hubungan antar kategori, flowchart, dan sejenisnya. Menurut Miles dan Huberman (Sugiyono 2010) yang paling sering digunakan untuk menyajikan data dalam penelitian kualitatif adalah dengan teks yang bersifat naratif. Selain menggunakan teks yang naratif, disarankan juga menggunakan grafik, matrik, network (jejaring kerja) dan chart.

\section{Verification}

Tahap ketiga adalah penarikan kesimpulan dan verifikasi. Kesimpulan awal yang dikemukakan masih bersifat sementara, dan akan berubah bila tidak ditemukan bukti-bukti yang kuat yang mendukung pada tahap pengumpulan data berikutnya. Tetapi apabila kesimpulan yang dikemukakan pada tahap awal, didukung oleh bukti-bukti yang valid dan konsisten saat peneliti kembali ke lapangan mengumpulkan data, maka kesimpulan akan dikemukakan merupakan kesimpulan yang kredibel.

\section{Analisis Data Instrumen}

Peneliti mengumpulkan data yang dibantu dengan instrumen pendukung yaitu angket penggolongan gaya belajar, tes penalaran matematis dan wawancara. Adapun analisisnya yaitu 
1. Analisis data angket gaya belajar

Pada tahap awal angket dibagikan kepada seluruh kelas XI IPS SMA Negeri 1 Rangkasbitung, yaitu kelas XI IPS 1, XI IPS 2 dan XI IPS 3, untuk mengetahui justifikasi awal siswa memiliki salah satu gaya belajar. Selanjutnya, angket diberikan kepada kelas subjek yaitu kelas XI IPS 2 karena hanya kelas XI IPS 2 mewakili dari ketiga gaya belajar yang peneliti harapkan. Angket gaya belajar selalu diberikan setelah siswa melaksanakan tes penalaran matematis. Adapun pedoman penskoran angket sebagai berikut:

Tabel 1. Pedoman Penskoran Angket

\begin{tabular}{lc}
\hline Keterangan & Skor \\
\hline Sering & 2 \\
Kadang-kadang & 1 \\
Jarang & 0 \\
\hline
\end{tabular}

Selanjutnya data hasil angket gaya belajar dianalisis dengan tahapan sebagai berikut :

a. Masing-masing butir pernyataan dikelompokkan sesuai dengan aspek yang diamati.

b. Berdasarkan pedoman penskoran yang telah dibuat, kemudian dihitung jumlah skor tiaptiap butir pernyataan sesuai dengan aspek-aspek yang diamati. Kemudian dihitung persentasenya dengan rumus sebagai berikut :

$$
\text { Persentase Golongan Belajar }(\%)=\frac{\text { Jumlah Skor }}{\text { Skor Maksimal }} x 100 \%
$$

c. Selanjutnya persentase yang lebih besar menunjukan bahwa golongan belajarnya.

2. Analisis data tes penalaran matematis

Hasil data penalaran matematis dianalisis secara deskriptif. Analisis terhadap penalaran matematis siswa dilakukan secara detail dimana peneliti menganalisis siswa cara menjawab soalnya yang disesuiakan dengan indikator yang sudah ditentukan.

3. Analisis data wawancara

Hasil wawancara dianalisis secara deskriptif. Analisis terhadap wawancara dengan siswa diharapkan dapat membantu untuk mengetahui hal-hal kebiasaan apa saja yang biasa dilakukan siswa selama belajar, hambatan-hambatan yang dialami, juga masukan positif guna memperbaiki penelitian selanjutnya.

\section{HASIL DAN PEMBAHASAN}

Gaya belajar seseorang terkadang suka berubah-ubah, banyak faktor yang dapat mempengaruhi salah satunya adalah lingkungan dan mood (suasana hati). Oleh karena itu 
untuk lebih meyakinkan gaya belajar dari subjek maka subjek diberikan angket gaya belajar kembali sebanyak tiga kali dengan waktu beriringan dengan tes penalaran matematis. Berikut hasil kumulatif gaya belajar kelas XI IPS 2 SMA Negeri 1 Rangkasbitung setelah pengisian angket gaya belajar sebanyak tiga kali.

Pada penelitian ini yang akan diteliti yaitu tiga gaya belajar saja yaitu visual, auditorial dan kinestetik. Dengan demikian banyaknya persentase pada gaya belajar di XI IPS 2 tergambarkan seperti Gambar 1.

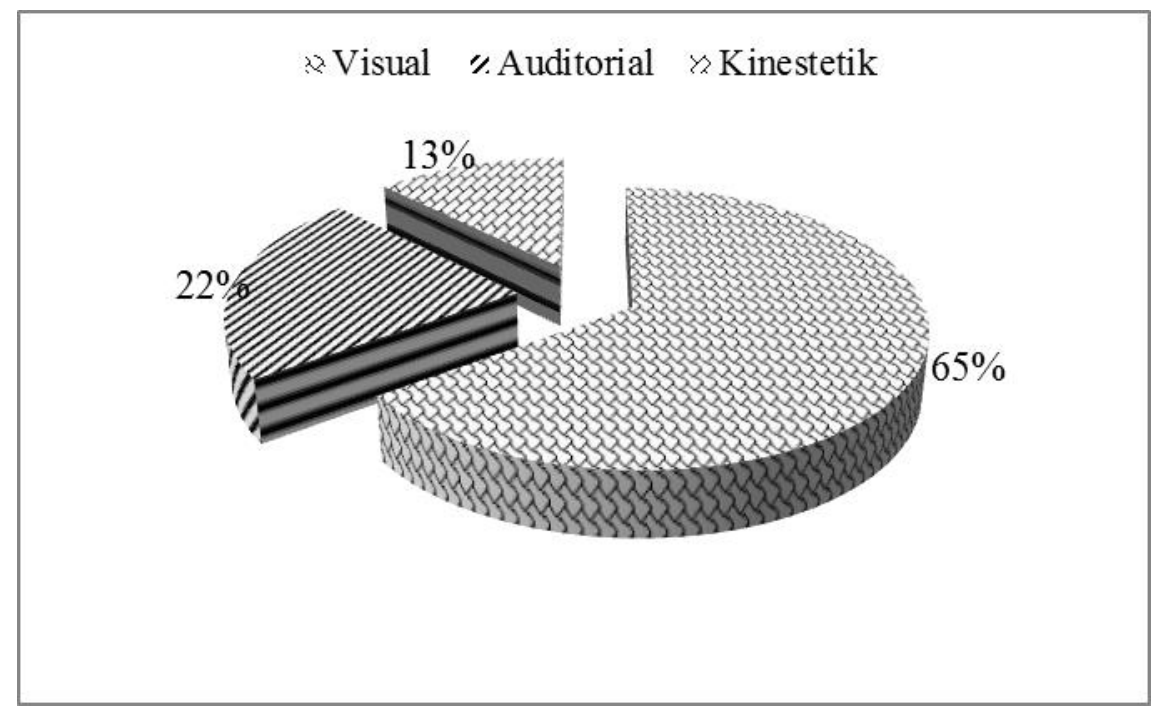

Gambar 1. Diagram Gaya Belajar XI IPS 2 SMA N 1 Rangkasbitung

Berdasarkan Gambar 1 kelas XI IPS 2 SMA Negeri 1 Rangkasbitung dengan siswa 40 orang terlihat bahwa siswa dengan gaya belajar visual terdapat 65\% (26 orang), gaya belajar auditorial terdapat 22\% (9 orang), dan gaya belajar kinestetik terdapat 13\% (5 orang) Untuk menentukan subjek penelitian dengan teknik purposive sampling, maka di dapat gaya belajar visual dipilih sebanyak tiga orang yaitu visual pertama $\left(\mathrm{V}_{1}\right)$, visual kedua $\left(\mathrm{V}_{2}\right)$, dan visual ketiga $\left(\mathrm{V}_{3}\right)$. Gaya belajar auditorial dipilih sebanyak empat orang yaitu auditorial pertama $\left(\mathrm{A}_{1}\right)$, auditorial kedua $\left(\mathrm{A}_{2}\right)$, auditorial ketiga $\left(\mathrm{A}_{3}\right)$ dan auditorial keempat $\left(\mathrm{A}_{4}\right)$, sedangkan gaya belajar kinestetik dipilih sebanyak dua orang yaitu kinestetik pertama $\left(\mathrm{K}_{1}\right)$, dan kinestetik kedua $\left(\mathrm{K}_{2}\right)$. Pemilihan ini berdasarkan pertimbangan dengan memperhatikan kriteria: (1) gaya belajar; (2) hasil tes kemampuan penalaran matematis; dan (3) tingkah laku siswa saat mengerjakan tes kemampuan penalaran matematis. Adapun secara rinci hasil angket gaya belajar dari sebagian yang tertera pada Tabel 2: 
Tabel 2. Gaya Belajar XI IPS 2 SMA Negeri 1 Rangkasbitung

\begin{tabular}{lccccccccccccc}
\hline \multirow{2}{*}{ Nama } & \multicolumn{3}{c}{ Pertama } & \multicolumn{4}{c}{ Kedua } & \multicolumn{1}{c}{ Ketiga } & \multicolumn{3}{c}{ Jumlah } & \multirow{2}{*}{ Gaya Belajar } \\
& V & A & K & V & A & K & V & A & K & V & A & K & \\
\hline Responden 8 & 15 & 21 & 14 & 15 & 6 & 11 & - & - & - & 30 & 27 & 25 & Visual $\left(\mathrm{V}_{1}\right)$ \\
Responden 14 & 10 & 13 & 14 & 15 & 12 & 13 & 17 & 12 & 13 & 42 & 37 & 40 & Visual $\left(\mathrm{V}_{2}\right)$ \\
Responden 16 & 20 & 15 & 12 & 9 & 11 & 11 & 12 & 12 & 10 & 41 & 38 & 33 & Visual $\left(\mathrm{V}_{3}\right)$ \\
Responden 10 & 9 & 12 & 6 & 16 & 18 & 10 & 17 & 17 & 12 & 42 & 47 & 28 & Auditorial $\left(\mathrm{A}_{1}\right)$ \\
Responden 12 & 8 & 9 & 6 & 14 & 16 & 10 & 13 & 17 & 9 & 35 & 42 & 25 & Auditorial $\left(\mathrm{A}_{2}\right)$ \\
Responden 30 & 12 & 10 & 12 & 15 & 19 & 15 & 15 & 22 & 16 & 42 & 51 & 43 & Auditorial $\left(\mathrm{A}_{3}\right)$ \\
Responden 42 & 14 & 14 & 11 & 10 & 12 & 12 & 11 & 13 & 12 & 35 & 39 & 35 & Auditorial $\left(\mathrm{A}_{4}\right)$ \\
Responden 13 & 12 & 10 & 13 & 10 & 10 & 13 & 8 & 11 & 9 & 30 & 31 & 35 & Kinestetik $\left(\mathrm{K}_{1}\right)$ \\
Responden 29 & 14 & 17 & 18 & 11 & 12 & 12 & 12 & 11 & 13 & 37 & 40 & 43 & Kinestetik $\left(\mathrm{K}_{2}\right)$ \\
\hline
\end{tabular}

Berdasarkan dari Tabel 2 terdapat 3 responden tergolong gaya belajar visual, 4 orang responden tergolong gaya belajar auditorial dan 2 orang responden tergolong gaya belajar kinestetik. Responden yang tertera pada Tabel 1 adalah subjek yang akan diteliti secara mendetail dari 40 orang kelas XI IPS 2 SMA Negeri 1 Rangkasbitung.

Kemampuan penalaran matematis memiliki empat indikator antara lain: manipulasi matematis, menarik kesimpulan, memberikan alasan atau bukti terhadap satu atau beberapa solusi dan memeriksa kesahihan suatu argumen. Untuk dapat melihat sejauh mana kemampuan penalaran matematis siswa dengan gaya belajar visual, auditorial, dan kinestetik akan dibahas berdasarkan hasil tes yang telah disesuaikan dengan indikator.

Dari hasil jawaban yang didapatkan dari ketiga subjek penelitian, bahwa dapat dikatakan subjek visual untuk memanipulasi cukup. Namun ide atau trik menuju ke tahap memanipulasi subjek visual telah menguasainya. Hal ini sejalan dengan De Potter \& Hernacki (2013) bahwa ciri-ciri siswa visual adalah perencana yang baik dan teratur. Begitu pula menurut Lucy dan Ade (2012) dalam deskripsinya bahwa seorang visual adalah perencana dan pengatur jangka panjang yang baik. 


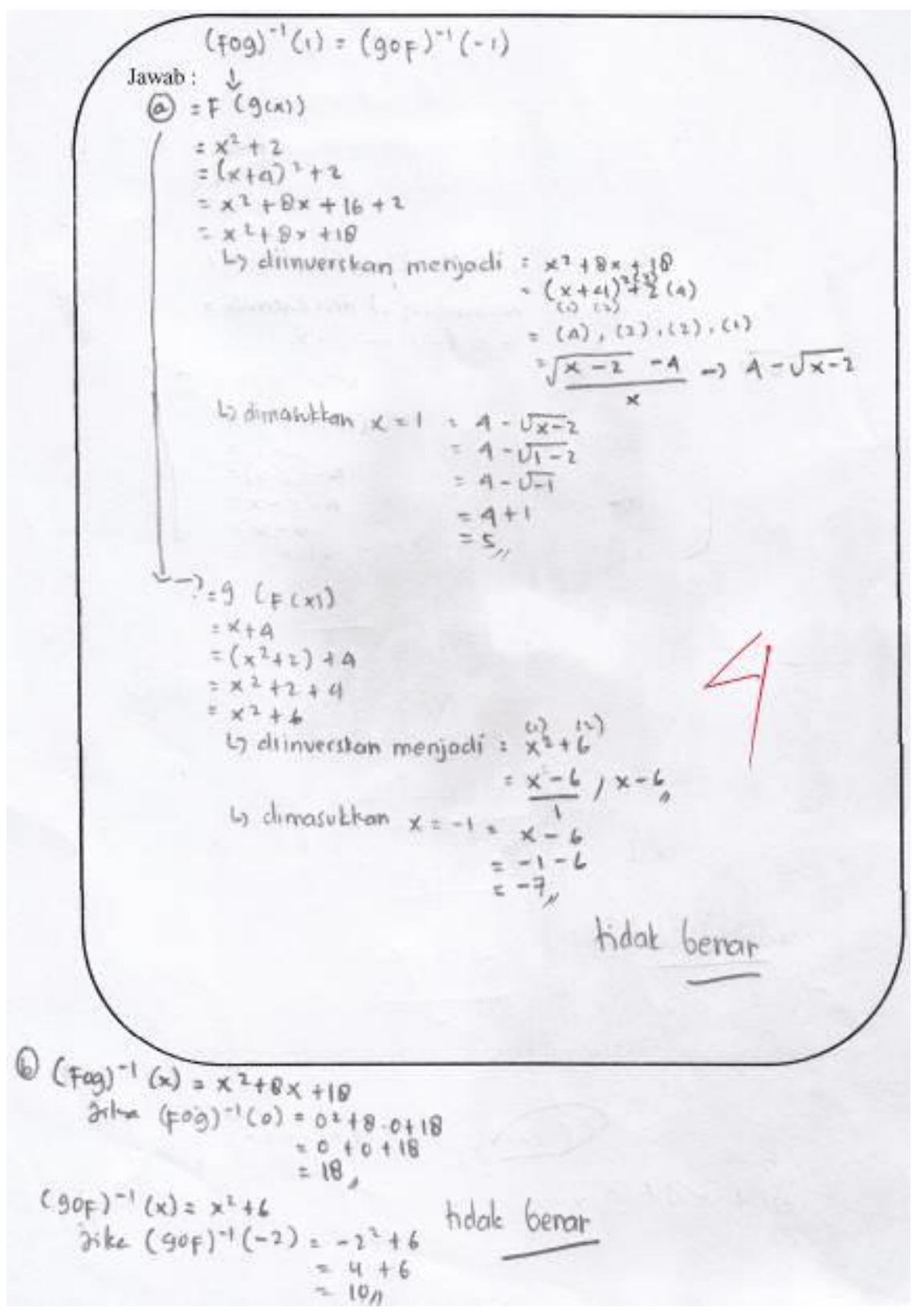

Gambar 2. Jawaban Siswa Visual

Indikator ketiga yaitu memberikan alasan atau bukti diperlukan ide atau trik untuk menjawab soalnya, siswa visual adalah perencana yang baik dan teratur (De Potter \& Hernacki 2013). Terbukti dengan jawabannya pada Gambar 2. jawaban siswa visual idenya memang sudah tepat dalam menjawab soal, hanya saja ketelitiannya kurang menyebabkan proses perhitungannya pun salah. Sehingga pada memberikan alasan atau bukti siswa visual termasuk cukup baik. Sejalan dalam memberikan kesahihan jawaban atau argumen. Argumen siswa 
visual yang diberikan hampir benar hanya saja lagi-lagi kurang teliti dalam mengerjakan soalnya, yang menyebabkan argumennya pun kurang tepat.

Pada tahap menarik kesimpulan siswa visual menarik kesimpulannya secara point per point.Pada proses perhitungannya siswa visual sudah benar, namun adanya sifat kurang percaya diri yang dimiliki oleh siswa visual. Memang benar kesimpulan dari point per point nya, namun yang diharapkan adalah kesimpulan secara keseluruhan, sehingga untuk siswa visual pada menarik kesimpulan cukup baik.

Dari hasil jawaban 4 orang auditorial bahwa dapat dikatakan siswa auditorial baik dalam memanipulasi. Terlihat jelas pada proses memanipulasinya walaupun dengan cara yang berbeda.

Tahap menarik kesimpulan siswa auditorial cukup baik, sebelum menarik kesimpulan siswa dituntut terlebih dahulu untuk menghitungnya setelah itu baru siswa dapat menyimpulkan dari hasil perhitungan. Dikarenakan proses perhitungannya tidak sampai selesai atau salah maka penarikan kesimpulannyapun salah. 


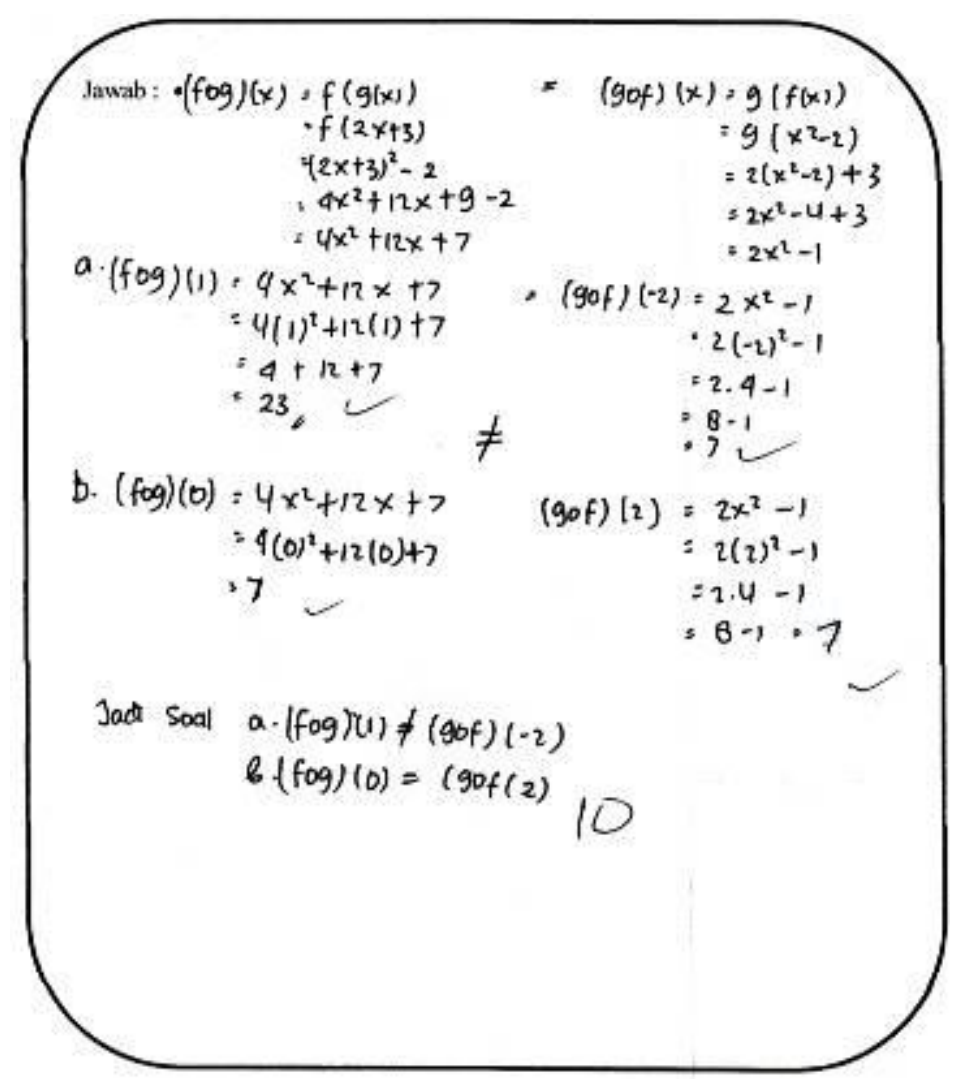

Gambar 3. Jawaban Siswa Auditorial

Gambar 3 jawaban siswa auditorial mendeskripsikan indikator memberikan argumen atau kesahihan jawaban siswa auditorial dan memberikan alasan atau bukti, bahwa siswa memberikan jawaban sangat jelas dalam memberikan argumennya. Hal ini sejalan dengan De Potter \& Hernacki (2013) siswa auditorial yaitu dalam menjelaskan sesuatu dengan panjang lebar. Pada aspek memberikan kesimpulan auditorial termasuk baik dalam memberikan alasan atau bukti, dimana siswa auditorial terlihat menginginkan cara yang lebih praktis yaitu menjawab dengan rumus cepat.

Dari hasil jawaban 2 orang subjek kinestetik memberikan jawaban pada aspek memanipulasi matematis dengan cukup. Pada tahap tersebut kinestetik tidak menuliskan apa yang diketahui, hal ini sejalan dengan penelitian Lucy dan Ade (2012) bahwa siswa kinestetik kurang lancar dalam menyebutkan apa yang diketahui dan ditanyakan. 


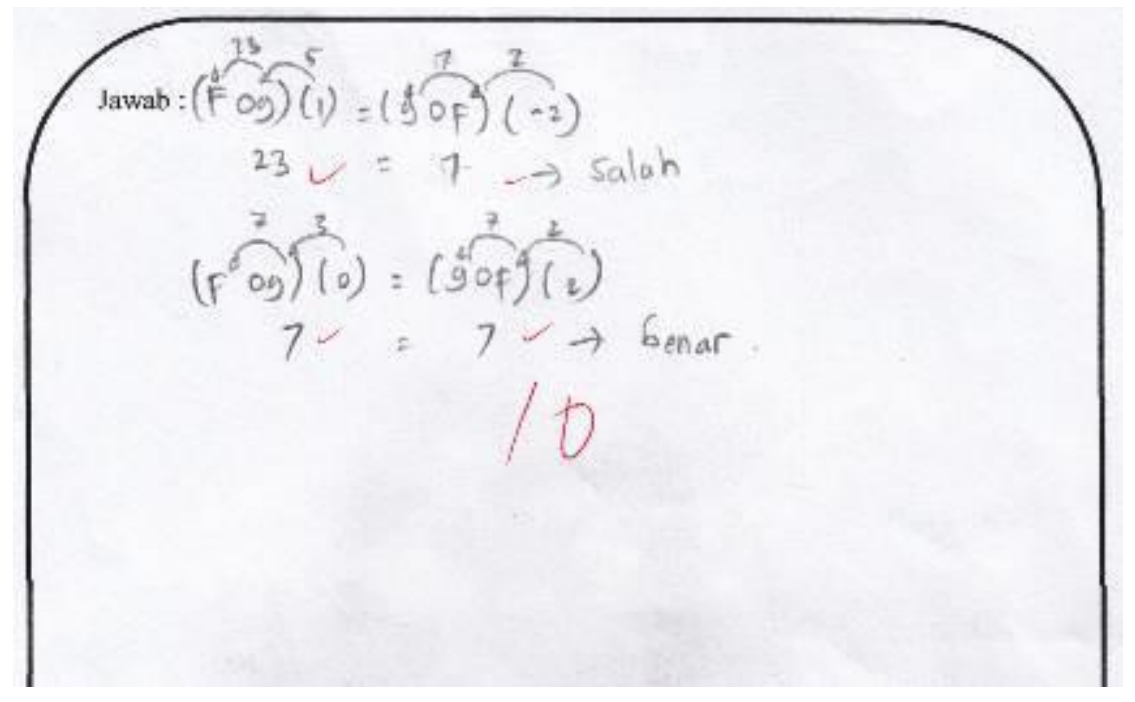

Gambar 4. Jawaban Siswa Kinestetik

Gambar 4. jawaban siswa kinestetik mendeskripsikan bahwa pada tahap memberikan alasan atau bukti, siswa kinestetik memberikan jawabannya dengan sederhana yaitu dengan rumus cepat dan unik. Hal ini sejalan dengan De Potter dan Hernacki (2013) bahwa siswa kinestetik adalah orang yang tidak mau ribet. Selanjutnya pada memberikan kesahihan jawaban atau argumen, dia memberikan jawaban dengan unik yaitu langsung mensubtitusikan ke fungsinya. Selain itu siswa kenesttetic dapat memberikan alasannya dengan benar. Sehingga siswa kinestetik baik dalam memberikan alasan. Terakhir dalam menarik kesimpulan siswa kinestetik kurang, karena tes yang diberikan siswa kinestetik secara dominan tidak menjawabnya.

\section{KESIMPULAN}

Berdasarkan hasil penelitian dan pembahasan maka dapat diambil kesimpulan bahwa profil kemampuan penalaran matematis siswa visual dan kinestetik memiliki kemampuan memanipulasi, menarik kesimpulan, memberikan alasan atau bukti adalah cukup. Kemampuan penalaran matematis siswa visual dalam memberikan argumennya kurang. Sedangkan, kemampuan penalaran matematis siswa dalam kinestetik dalam menarik kesimpulannya kurang, serta kemampuan memberikan kesahihan jawaban atau argumen, ia memberikan jawaban dengan unik dan jelas. Profil kemampuan penalaran matematis siswa auditorial memiliki kemampuan memanipulasi, memberikan alasan atau bukti, dan memberikan argumen atau kesahihan jawaban adalah baik. Sedangkan, menarik kesimpulannya cukup. 


\section{REKOMENDASI}

Penelitian profil kemampuan penalaran matematis yang ditinjau dari gaya belajar (visual, auditorial, dan kinestetik) ini memiliki keterbatasan penelitian, untuk memperoleh hasil yang lebih sempurna maka dipandang perlu untuk dilakukan penelitian-penelitian sejenis dimasa yang akan datang. Penulis menyarankan di setiap sekolah diadakan tes gaya belajar, agar guru tahu gaya belajar masing-masing siswa sehingga dalam KBM (Kegiatan Belajar Mengajar) guru dapat menyesuaikan gaya mengajar dengan berbagai metode yang sekiranya cocok dengan gaya belajar siswa, dengan melakukan semua ini maka akan mempertinggi efektifitas KBM di Sekolah dan setiap siswa diberikan pengertian mengenai gaya belajar sehingga mereka dapat menyesuaikan gaya belajar sehingga mereka dapat menyesuaikan gaya belajar yang dimilikinya. Hal ini merupakan salah satu cara untuk meningkatkan kemampuan penalaran matematis.

\section{REFERENSI}

Azmi, U. (2013). Profil Kemampuan Penalaran Matematika dalam Menyelesaikan Masalah Matematika ditinjau dari Kemampuan Matematika pada Materi Persamaan Garis Lurus Kelas VIII SMP YPM 4 Bohar (Disertasi Doktor, UIN Sunan Ampel Surabaya).

Creswell, J. (2013). Research Design Pendekatan Kualitatif, Kuantitatif, dan Mixed. Yogyakarta: Pustaka Pelajar.

De Potter, B. \& Hernacki, M. (2013). Quantum Learning: Membiasakan Belajar Nyaman dan Menyenangkan. Bandung: Kaifa.

Keliat, N. R. (2016). The Profile of Students' Learning Styles and Their Effects on Grade Point Average (GPA) Achievement. EDUTECH, 15(2), 188-198.

Kamus Besar Bahasa Indonesia Online terdapat pada http://kbbi.web.id

Kemendikbud. (2014). Permendikbud Nomor 59 Tahun 2014 Tentang Kurikulum2013 Sekolah Menengah Atas/ Madrasah Aliyah. Jakarta: Kemendikbud.

Lucy, B. dan Rizky, A.J. (2012). DAHSYATNYA BRAIN SMART TEACHING Cara Super Jitu Optimalkan Kecerdasan Otak dan Prestasi Belajar Anak. Bogor: Penebar Plus ${ }^{+}$.

Permendiknas Republik Indonesia Nomor 22 Tahun 2006 Tentang Standar Isi.

Sugiyono. (2010). Metode Penelitian Pendidikan Pendekatan Kuantitatif, kualitatif, dan R\&D. Bandung: Alfabeta. 